\title{
Effects of maturity and harvest season of grass-clover silage and of forage-to-concentrate ratio on milk production of dairy cows
}

\author{
L. Alstrup, ${ }^{*}$ K. Søegaard, $†$ and M. R. Weisbjerg* ${ }^{* 1}$ \\ *Department of Animal Science, and \\ †Department of Agroecology, AU Foulum, Aarhus University, DK 8830 Tjele, Denmark
}

\begin{abstract}
This study examined the effects of maturity and season of harvest of grass-clover silages and forage:concentrate ratio (FCR) on feed intake, milk production, chewing activity, digestibility, and fecal consistency of Holstein dairy cows. Comparison included 2 cuts in spring season (early and late) and 2 cuts in summer season (early and late) combined with high FCR (80:20; HFCR) and low FCR (50:50; LFCR). The experiment included 24 lactating Holstein cows arranged as 2 repeated $4 \times$ 4 Latin squares with four 21-d periods and included measurements of feed composition, feed intake, milk production and composition, chewing activities, digestibilities, and fecal dry matter (DM) concentration and scoring. Forages were fed as two-thirds grass-clover and one-third corn silage supplemented with either 20 or $50 \%$ concentrate. Rations were fed ad libitum as total mixed rations. Early maturity cuts were more digestible than late maturity cuts, which was also reflected in a lower concentration of neutral detergent fiber (NDF) in early maturity cuts, whereas summer cuts had a higher crude protein concentration than spring cuts. Increased maturity decreased the intake of DM and energy, increased NDF intake, and decreased the yield of energy-corrected milk (ECM). Summer cuts increased the ECM yield compared with spring cuts. Milk yield ( $\mathrm{kg}$ and kilogram of ECM) was numerically higher for cows fed early summer cut, independent of FCR in the ration. Milk protein concentration decreased, or tended to decrease, with maturity. For LFCR, the milk fat concentration increased with maturity resulting in a decreased protein:fat ratio. At HFCR, increased maturity increased the time spent chewing per kilogram of DM. Digestibility of silages was positively correlated with the fecal DM concentration. The DM intake and ECM yield showed no significant response to FCR in the ration, but the milk composition was affected. The LFCR decreased the milk fat percentage and increased the
\end{abstract}

Received May 11, 2015.

Accepted September 9, 2015.

${ }^{1}$ Corresponding author: Martin.Weisbjerg@agrsci.dk milk protein percentage numerically followed by a higher protein:fat ratio. Total chewing time per kilogram of DM decreased and total chewing time per kilogram of NDF increased with LFCR. This study indicates that silages from summer cuts have a similar value for milk production as do spring cuts, when forage digestibility is taken into account. Moreover, it appears that supplementation of extra concentrate has no effect on ECM production when forages with a high digestibility are fed, and that the physical structural value is adequate even when feeding high digestible forages.

Key words: digestibility, forage, grass-clover maturity, milk yield

\section{INTRODUCTION}

The composition of forages and forage-to-concentrate ratio (FCR) has variable effects on both feed intake and rumen fermentation and thereby milk production and composition (Sutton, 1989). Strategy of harvest, including maturity of crop and season, are important for the yield and feeding value of the forage. Digestibility and expected feed intake of the relevant forage, allocation of nutrients and milk yield, and composition will be influenced by these factors (Rinne, 2000). Harvest of grass for silage at an early stage of maturity is expected to result in silage with a high concentration of energy and CP and may thereby be a prerequisite for high energy intake and production (Randby et al., 2010, 2012). Feed intake depends on both physical characteristics and chemical composition of the ration (Mertens, 1997) and is therefore influenced both by digestibility and rate of passage from the rumen (Beauchemin and Yang, 2005). Prediction of feed intake is fundamental for formulation of feed rations because variation in performance of the cow is more closely related to feed intake than to digestibility of the ration fed (; Huhtanen et al., 2007). However, digestibility of the ration will also have an effect on milk yield because intake is related to $\mathrm{OM}$ digestibility (OMD; Huhtanen et al., 2007).

The concentration of NDF in the ration is important to maintain the ruminal function and to maximize milk yield. Digestibility of NDF varies a lot among different 
forages and affects performance of the cow, as increased NDF digestibility increases DMI and ECM (Oba and Allen, 1999).

The effect of the FCR has been examined in various studies (Yang et al., 2001; Dewhurst et al., 2002; Andersen et al., 2003; Kuoppala et al., 2008; Steinshamn and Thuen, 2008; Steinshamn et al., 2008) to obtain the optimal proportion while a high milk production is still maintained. Decreased FCR generally results in increased DMI, milk production, and milk protein concentration and decreased milk fat concentration. Allen (2000) claims that it is the amount and digestibility of forage fiber and a propionate limiting effect on DMI rather than a specific FCR that is associated with the results. Because concentrate is often more expensive than home-grown forages, maximizing the proportion of forage is of economic importance.

The aim of the present study was to examine the effect of grass-clover silages harvested at different maturity stages and different seasons combined with different FCR on feed intake, milk production, and chewing activity of dairy cows. The hypotheses were that the high digestible forage would fulfill the requirement for physical structure due to increased feed intake, although the content of fiber is low, and that milk production is independent of season if digestibilities of forages are similar.

\section{MATERIALS AND METHODS}

\section{Silage Preparation}

Grass-clover from a mixed sward of perennial ryegrass-red clover, containing less than $1 \%$ white clover, was harvested in 2009 at AU-Foulum, Denmark, in 4 different cuts for silage. The Danish climate is temperate, and the average temperature and global radiation were $10.8,13.4,16.4$, and $16.5^{\circ} \mathrm{C}$ and $19.6,22.4$, 17.1, and $15.0 \mathrm{MJ} / \mathrm{m}^{2} / 24 \mathrm{~h}$ for May, June, July, and August, respectively. The 4 cuts consisted of an early first cut (May 9) in spring (ESP), a second cut with long regrowth (June 22, 42-d regrowth) in spring/early summer (LSP), an early fourth cut (August 7, 2009, 17-d regrowth) in summer (ESU), and a late fourth cut (August 23, 2009, 33-d regrowth) in summer (LSU). After pre-wilting to approximately $40 \%$ DM, herbage was chopped to $19.2 \mathrm{~mm}$ theoretical length of cutting by a forage harvester (John Deere 6750). After precision chopping, the material was transported to a clean area and mixed, to make the material homogenous, before round bales were made (diameter $125 \mathrm{~cm}$; Orkel MP 2000 Compactor, Orkel, Fannrem, Norway) and ensiled by wrapping 11 layers of $25-\mu \mathrm{m}$ plastic without use of ensiling additives. For botanical and morphological analysis, samples were collected from all cuts immediately after harvest. Morphological analysis was conducted by manually dissecting the fresh crop into grass leaves, grass stems including leaf sheaths, red clover leaves, red clover stems including flowers and stipules, white clover leaves, and white clover flowers. Corn whole crop was harvested on October 25, 2009, at a theoretical length of cutting of $13.5 \mathrm{~mm}$ using a kernel processor $(3.5 \mathrm{~mm})$. Corn whole crop was ensiled in an indoor bunker silo without any use of ensiling additives.

\section{Experimental Design and Rations}

The experiment was carried out at AU Foulum, Tjele, Denmark, and complied with the guidelines set out by the Danish Ministry of Justice with respect to animal experimentation and the care of animals used for scientific purpose.

Twenty-four lactating Holstein Friesian cows in first half of lactation were used in this study. At the beginning of the experiment, cows averaged ( \pm SEM) $578 \pm$ $14 \mathrm{~kg}$ of BW, $2.9 \pm 0.24$ in BCS, $104 \pm 8$ DIM, 37.2 $\pm 6.4 \mathrm{~kg}$ of ECM, and $22.9 \pm 2.8 \mathrm{~kg}$ of DMI. The experimental design was a $4 \times 4$ Latin square with four 21 -d periods and a $2 \times 2$ factorial arrangement of treatments with either high FCR (HFCR) or low FCR (LFCR), giving a total of 8 rations and 3 cows on each ration per period. Cows were assigned to 3 blocks, according to parity (first, second, and older cows).

Cows were tied up individually in beds covered with mattresses and sawdust. Cows were milked twice daily at 0500 and $1600 \mathrm{~h}$. Feed was offered as TMR mixed daily in an auger feed mixer for $12 \mathrm{~min}$. Total mixed ration was offered 2 times daily (0730 and $1400 \mathrm{~h}$ ) ad libitum (a minimum of $5 \%$ residuals) in equal-size portions. Residuals were removed and weight recorded before the morning feeding. Cows had free access to drinking water.

Forage consisted, on DM basis, of two-thirds grassclover (ryegrass-red clover) silage and one-third corn silage, and were either fed as HFCR (80:20) or LFCR (50:50). High and low FCR were defined according to Danish practice, where FCR on 60:40 is common (Kristensen et al., 2015).

Feed intake was based on registrations in the last week of each period. Chewing activity was measured for $24 \mathrm{~h}$ for each cow, and as only 4 cows could be measured simultaneously, measurements were made from d 6 to 21 of each period. Milk data were derived from the last $3 \mathrm{~d}$ of each period. Samples of feces derived from 6 subsamples taken the last $3 \mathrm{~d}$ of each period. 


\section{Experimental Procedures and Chemical Analyses}

Feed Composition. Fresh silage was sampled every time a new bale of grass-clover silage was opened. At the same days, samples were taken of corn silage and the concentrates. All feed samples were frozen $\left(-20^{\circ} \mathrm{C}\right)$. Samples were dried at $60^{\circ} \mathrm{C}$ for $24 \mathrm{~h}$ and milled through a 1-mm screen before chemical analysis. Samples were analyzed for ash by combustion at $525^{\circ} \mathrm{C}$ for $6 \mathrm{~h}$ (AOAC International, 2000). Crude protein was calculated as $6.25 \times$ total $\mathrm{N}$ concentration measured by Dumas principle as described by Hansen (1989) using a Vario MAX CN (Elementar Analysesysteme GmbH, Hanau, Germany). Crude fat was measured by Soxhlet extraction with petroleum ether after hydrolysis with hydrochloric acid (Stoldt, 1952). The NDF concentration was measured by a Fibertec M6 System (Foss Analytical, Hillerød, Denmark) using heat-stable amylase to remove starch followed by neutral detergent boiling as described by Mertens (2002). Indigestible NDF was determined as residual NDF in Dacron bags with a pore size of $12 \mu \mathrm{m}$ after $288 \mathrm{~h}$ incubation in $3 \mathrm{ru}-$ men fistulated nonlactating Holstein Friesian cows fed a standard ration (Åkerlind et al., 2011). Total sugar in grass silage was extracted with diluted ethanol and analyzed by the Luff-Schoorl method (71/250/EEC; Schoorl, 1929). Starch was measured by the enzymatic colorimetric technique (Knudsen et al., 1987). Water extracts of wet silage samples were prepared by homogenizing $100 \mathrm{~g}$ of silage with $1,000 \mathrm{~g}$ of deionized water for $2 \times 40 \mathrm{~s}$ in a blender (Waring 24CB10; Waring Commercial, New Hartford, CT); $50 \mathrm{~mL}$ of the homogenized sample was stored on ice until centrifuged $(2,500$ $\times g$ at $10^{\circ} \mathrm{C}$ for $10 \mathrm{~min}$; Nielsen et al., 2007). Silage extracts were stabilized with meta-phosphoric acid and analyzed for free glucose and L-lactate using D-glucose oxidase and L-lactate oxidase, respectively (YSI 7100; YSI Inc., Yellow Springs, OH), acetate, propionate, and butyrate by gas chromatography and ammonia in samples diluted 1:20 with phosphate buffer using an enzymatic assay (AM 1015; Randox Laboratories Ltd., Crumlin, UK) adapted for use on a Cobas Mira auto analyzer (Triolab A/S, Brondby, Denmark; Kristensen et al., 2010). Concentrations of ethanol, propyl acetate, and 2-butanol in extracts were determined as described by Kristensen et al. (2007) except for adding [2-13C] ethanol (99\%, Cambridge Isotope Laboratories Inc., Andover, MA) and [1,2-13C]ethyl acetate (99\%, Cambridge Isotope Laboratories Inc.) as internal standards for ethanol and propyl acetate, respectively. Butanol, ethyl acetate, and $\mathrm{pH}$ were measured as described by Kristensen et al. (2010). In vitro digestibility of OM in forages was performed by anaerobic incubation with diluted rumen fluid for $48 \mathrm{~h}$, followed by incubation of undissolved material with pepsin $\mathrm{HCl}$ solution for $48 \mathrm{~h}$ (Tilley and Terry, 1963). In vitro digestibility of OM of concentrates was determined by treating samples with pepsin $\mathrm{HCl}$ solution followed by enzyme incubation (Weisbjerg and Hvelplund, 1993). Digestibilities of OM were subsequently estimated according to Åkerlind et al. (2011).

Feed Intake. Feed offered and orts were recorded daily during the whole period. At the last day of each period, a sample was taken of orts for DM determination.

Chewing Activities. Chewing activities of the cows were monitored electronically for a 24 -h period during each period. Cows were fitted with halters of the trade IGER (Ultra Sound Advice, London, UK), equipped with special noseband sensors, head collar, and a box for automatic recording of data. Data were analyzed in the PC program "Graze" (Ultra Sound Advice) by designating jaw movements as eating or ruminating chews (Rutter, 2000). Activities were expressed on basis of DM and NDF intake by dividing eating or ruminating time by intake.

Milk Production and Composition. In the third week of each period, milk yield and composition were recorded over $3 \mathrm{~d}$. Milk samples were stored at $5^{\circ} \mathrm{C}$ and analyzed for protein, fat, and lactose at Eurofins (Holstebro, Denmark) on a Milkoscan 4000 infrared analyzer (Foss Electric, Hillerod, Denmark). Analysis of BHB was done as described by Larsen and Nielsen (2005) based on an enzymatic method where developed NADH is coupled with resazurin, producing equimolar levels of the fluorescent compound resorufin. Uric acid was analyzed by enzymatic oxidation of uric acid via uricase, coupling of hydrogen peroxide and a nonfluorometric precursor, and subsequent measurement of the fluorescent product resorufin as described by Larsen and Moyes (2010). Milk urea was analyzed using flow injection analyses (Foss Tecator AB, Höganäs, Sweden) measuring ammonia spectrophotometrically after urease (EC 3.5.1.5) hydrolysis. The application note given by the manufacturer was followed (Foss Tecator AB; Nielsen et al., 2005).

Feces Sampling. During the last 3 d of each period, fecal grab samples of approximately $200 \mathrm{~mL}$ were collected twice daily at 0900 and $1500 \mathrm{~h}$ and stored at $-20^{\circ} \mathrm{C}$. Mixed thawed samples were scored for consistency by 2 people (scale 1-5), and DM concentrations of fecal samples were determined by drying approximately $2 \times 200 \mathrm{~mL}$ of each sample in a forced-air oven at $60^{\circ} \mathrm{C}$ for $48 \mathrm{~h}$.

$\boldsymbol{B} \boldsymbol{W}$ and $\boldsymbol{B C S}$. Cows were weighed and BCS was assessed at the beginning and end of each period. Weigh- 
ing was performed on a platform scale. The BCS was based on a visual assessment of the pelvic region only as described by Ferguson et al. (1994). This method operates with $1 / 4$ point intervals on a scale of 1 to 5 .

\section{Calculations and Statistical Analysis}

Net energy content of feedstuffs was measured as Scandinavian feed units and was converted to $\mathrm{NE}_{\mathrm{L}}$ $(\mathrm{MJ} / \mathrm{kg}$ of $\mathrm{DM})$ using the fixed conversion coefficient $7.89 \mathrm{MJ}$ of $\mathrm{NE}_{\mathrm{L}} /$ Scandinavian feed units (Weisbjerg and Hvelplund, 1993). Energy-corrected milk (3.140 $\mathrm{MJ} / \mathrm{kg}$ ) was calculated as described by Sjaunja et al. (1991) using the following equation: ECM yield $(\mathrm{kg})=$ milk yield $(\mathrm{kg}) \times[(38.3 \times$ fat $(\mathrm{g} / \mathrm{kg})+24.2 \times$ protein $(\mathrm{g} / \mathrm{kg})+15.71 \times$ lactose $(\mathrm{g} / \mathrm{kg})+20.7) / 3,140]$.

Experimental data were analyzed with procedures of SAS version 9.2 (2010, SAS Institute Inc., Cary NC). Data from one cow were omitted during one period due to mastitis. However, BW and BCS data of this cow were fully omitted. The ANOVA on DM and nutrient uptake and milk production and composition was performed using the MIXED models procedure of SAS. The model included the effect of period, season, maturity, and season $\times$ maturity as fixed effects with cow as random. For analysis of BW, BCS, chewing time, and feces, the general linear model procedure was used including effects of block, cow, period, season, maturity, and season $\times$ maturity. An analysis comparing HFCR and LFCR was performed using the mixed models procedure. Covariates were calculated for DMI and ECM yield of individual cows from the mean of results obtained during the $5 \mathrm{~d}$ up to the experiment start. Covariate DMI was used for feed intake and chewing activity, and covariate ECM was used for milk production and composition. The model included the calculated covariate, period, FCR, season, maturity, season $\times$ maturity, and FCR $\times$ season $\times$ maturity. Block and cow were set as random. For analysis of feces and digestibility, covariates were not used.

Results reported in tables are, if not otherwise mentioned, treatment least squares means and SEM. Probability values $\leq 0.05$ were regarded as significant, $P \leq$ 0.10 as tendencies.

\section{RESULTS}

\section{Forage Quality and Composition}

The botanical composition of the 4 grass-clover cuts was measured by dividing them into grass and clover and into leaves and stem. Ratios of grass:clover were 71:29, 63:37, 68:32, and 60:40 for ESP, LSP, ESU, and
LSU, respectively, which were as expected. Clover consisted of approximately $2 \%$ white clover and $98 \%$ red clover. Ratios of leaves:stem as an average of species were 80:20, 44:56, 94:6, and 92:8 for ESP, LSP, ESU, and LSU, respectively.

In Table 1, the chemical compositions of the 4 different grass-clover silages, corn silage, and concentrates are shown, and compositions of the 8 different rations are shown as percentages of total ration on a DM basis in Table 2. The ESP was characterized by the lowest concentration of NDF and the highest DM, sugar, and glucose concentration and digestibility. A high DM concentration indicates a restrictive fermentation, which is expressed in low lactate and high sugar concentrations and high $\mathrm{pH}$ value compared with the other cuts. The concentration of ethanol was also high compared with the other cuts. The highest concentration of NDF was measured in LSP combined with the lowest digestibility, whereas ESU was characterized by the highest concentration of protein. The LSP and LSU had similar digestibilities, whereas the NDF concentration was higher in LSP. The concentration of NDF was almost the same in ESU and LSU. Ethanol decreased and lactate increased from spring to summer cuts and with increased maturity. In general, propionate, butyrate, 2-butanol, butanol, ethylacetate, and propylacetate were low, indicating 4 silages of good quality. Composition of rations reflects composition of silages according to the concentrations of $\mathrm{CP}$ and NDF (Tables 1 and 2).

\section{$D M I, B W$, and $B C S$}

Effects of forage maturity and season on feed intake are presented in Table 3. Increased maturity decreased intake of DM and energy and increased NDF intake irrespective of FCR. At HFCR, an interaction was found between maturity and season, as intake was the same for ESP and ESU and increased from LSP to LSU. The HFCR combined with LSP resulted in the lowest intake.

Neither maturity, season, nor maturity $\times$ season affected BW, BCS, or changes. For HFCR, the weight change over the whole experiment was $5.3 \mathrm{~kg}$ and for LFCR $10.6(P=0.04)$. The FCR showed no effect on BCS $(P=0.9)$, as HFCR showed a change BCS of 0.005 and LFCR 0.00 .

\section{Chewing Activity}

Chewing activity is shown in Table 3, specified into ruminating, eating, and total chewing time (min) per kilogram of DMI and kilogram intake of NDF. Total chewing time per kilogram of DM increased with 
increased maturity stage at HFCR, whereas LFCR seemed to mask this effect. Increased stage of maturity increased total chewing time numerically on both high and low FCR (except for NDF at LFCR).

The ratios of time spent ruminating to time spent eating at HFCR was measured to be 1.4, whereas the relationship at LFCR varied between 1.5 and 1.8. Across FCR, ration LSP resulted in the longest total chewing time.

\section{Milk Yield and Composition}

Table 4 shows the milk yield and composition. Increased maturity stage decreased milk yield in spring, and summer cuts resulted in a higher milk yield than spring cuts for both FCR. However, the interaction between forage maturity $\times$ season seemed to be diluted by LFCR. The numerically highest milk yield ( $\mathrm{kg}$ and $\mathrm{kg}$ of $\mathrm{ECM}$ ) was obtained with ESU, independent of FCR. In both experiments, kilograms of $\mathrm{ECM} / \mathrm{NE}_{\mathrm{L}}$ were increased in summer cuts and increased or tended to increase with stage of maturity.
Milk fat concentration tended to increase and protein concentration tended to decrease with increased maturity. Ratio of protein:fat decreased with increased maturity stage in spring. Urea concentration decreased with maturity in HFCR and increased from spring to summer. Stage of maturity increased the concentration of BHB at HFCR, whereas the BHB concentration decreased from spring to summer. Neither stage of maturity nor season affected the concentration of uric acid.

\section{Feces}

Ration digestibilities are shown in Table 5 together with fecal DM and consistency score. Digestibility of DM decreased with increased maturity for both HFCR and LFCR, and OMD followed the same pattern. The NDF digestibility was higher in summer for HFCR and tended to decrease with maturity for LFCR. An interaction was found between maturity and season on HFCR on digestibility of ash, as the digestibility increased with increased maturity in spring and decreased with increased maturity in summer. For LFCR, digestibility

Table 1. Chemical composition (\% of DM unless noted) of grass-clover silages, corn silage, and concentrates ${ }^{1}$

\begin{tabular}{|c|c|c|c|c|c|c|c|}
\hline \multirow[b]{2}{*}{ Item } & \multicolumn{7}{|c|}{ Feedstuff $^{2}$} \\
\hline & ESP & LSP & $\mathrm{ESU}$ & LSU & Corn silage & Conc. HFCR & Conc. LFCR \\
\hline DM, \% of fresh matter & 46.6 & 40.0 & 43.8 & 35.0 & 35.6 & 85.9 & 85.6 \\
\hline Ash & 8.7 & 9.1 & 10.5 & 10.2 & 3.2 & 11.5 & 6.9 \\
\hline $\mathrm{CP}$ & 19.2 & 15.3 & 27.7 & 23.9 & 9.8 & 28.8 & 22.8 \\
\hline Crude fat & 3.7 & 2.7 & 4.8 & 4.2 & 2.7 & 2.1 & 2.0 \\
\hline $\mathrm{NDF}$ & 30.8 & 44.1 & 36.2 & 37.3 & 42.7 & 7.9 & 9.0 \\
\hline Indigestible NDF & 3.0 & 7.4 & 3.7 & 5.7 & 8.2 & & \\
\hline Starch & & & & & 26.3 & 32.7 & 43.1 \\
\hline Sugar & 18.3 & 6.3 & 0.8 & 1.6 & 0.1 & & \\
\hline Acetic acid, $\mathrm{g} / \mathrm{kg}$ of DM & 4.0 & 15.0 & 13.9 & 14.2 & 15.9 & & \\
\hline Ethanol, $\mathrm{g} / \mathrm{kg}$ of DM & 8.5 & 3.3 & 3.5 & 2.1 & 6.6 & & \\
\hline Lactate, ${ }^{3} \mathrm{~g} / \mathrm{kg}$ of DM & 7.2 & 22.5 & 29.3 & 32.1 & 20.6 & & \\
\hline Glucose, $\mathrm{g} / \mathrm{kg}$ of DM & 49.1 & 17.4 & 1.9 & 7.1 & 0.2 & & \\
\hline $\mathrm{NH}_{3}-\mathrm{N} / \mathrm{N}, 4 \%$ & 5.4 & 5.9 & 4.4 & 6.2 & 7.4 & & \\
\hline Propionate & & & & & 0.1 & & \\
\hline Butyrate & & & & & 0.0 & & \\
\hline 2-Butanol & 0.0 & 0.1 & 0.1 & 0.1 & 0.3 & & \\
\hline Butanol & 0.01 & 0.00 & 0.00 & 0.01 & 0.00 & & \\
\hline Ethylacetate & 3.7 & 5.2 & 5.5 & 3.0 & 18.0 & & \\
\hline Propylacetate & 0.0 & 0.2 & 0.1 & 0.1 & 2.9 & & \\
\hline $\mathrm{pH}$ & 5.3 & 4.2 & 4.4 & 4.4 & 3.9 & & \\
\hline $\mathrm{OMD},{ }^{5} \%$ & 81.3 & 73.5 & 77.0 & 73.9 & 74.7 & 90.5 & 90.5 \\
\hline $\mathrm{NE}_{\mathrm{L}},{ }^{6} \mathrm{MJ} / \mathrm{kg}$ of $\mathrm{DM}$ & 7.75 & 6.24 & 7.55 & 6.90 & 7.40 & 9.27 & 9.51 \\
\hline
\end{tabular}

${ }^{1}$ Mean for DM concentration is for 12 samples composited by period, and other parameters are from 4 composite samples.

${ }^{2}$ Early spring cut (ESP), late spring cut (LSP), early summer cut (ESU), and late summer cut (LSU) grass-clover silage. Concentrate (Conc.) used for high forage-to-concentrate ratio (80:20; HFCR) and low forage-to-concentrate ratio (50:50; LFCR).

${ }^{3} \mathrm{~L}$-part of lactate; concentration of total lactate is approximately twice as much.

${ }^{4}$ Ammonia N, \% of total N.

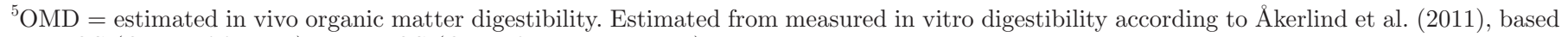
on IVOS (OMD of forages) and EFOS (OMD for all remaining).

${ }^{6} \mathrm{NE}_{\mathrm{L}}$ is calculated according to Weisbjerg and Hvelplund (1993). 
Table 2. Ration ingredients and chemical composition of rations

\begin{tabular}{|c|c|c|c|c|c|}
\hline \multirow[b]{2}{*}{$\mathrm{FCR}^{1}$} & \multirow{2}{*}{$\begin{array}{l}\text { Ingredient } \\
\text { (\% of DM unless noted) }\end{array}$} & \multicolumn{4}{|c|}{ Treatment $^{2}$} \\
\hline & & ESP & LSP & ESU & LSU \\
\hline \multirow[t]{3}{*}{ HFCR } & Concentrate premix $\mathrm{HFCR}^{3}$ & 20 & 20 & 20 & 20 \\
\hline & Corn silage & 26.7 & 26.7 & 26.7 & 26.7 \\
\hline & Grass-clover silage & 53.3 & 53.3 & 53.3 & 53.3 \\
\hline \multirow[t]{3}{*}{ LFCR } & Concentrate premix $\mathrm{LFCR}^{3}$ & 50 & 50 & 50 & 50 \\
\hline & Corn silage & 16.7 & 16.7 & 16.7 & 16.7 \\
\hline & Grass-clover silage & 33.3 & 33.3 & 33.3 & 33.3 \\
\hline \multirow[t]{8}{*}{ HFCR } & $\mathrm{DM}^{4} \%$ & 47.1 & 43.3 & 45.5 & 40.0 \\
\hline & $\mathrm{Ash}_{2}^{5} \%$ of DM & 7.8 & 8.0 & 8.8 & 8.6 \\
\hline & $\mathrm{CP},{ }^{5} \%$ of $\mathrm{DM}$ & 18.6 & 16.5 & 23.1 & 21.1 \\
\hline & Crude fat, ${ }^{5} \%$ of DM & 3.1 & 2.6 & 3.7 & 3.4 \\
\hline & $\mathrm{NDF},{ }^{5} \%$ of $\mathrm{DM}$ & 29.4 & 36.5 & 32.3 & 32.9 \\
\hline & Forage NDF, ${ }^{5} \%$ of total NDF & 94.6 & 95.7 & 95.1 & 95.2 \\
\hline & Sugar, ${ }^{6} \%$ of DM & 11.1 & 4.7 & 1.8 & 2.2 \\
\hline & $\mathrm{NE}_{\mathrm{L}},{ }^{7} \mathrm{MJ} / \mathrm{kg}$ of $\mathrm{DM}$ & 7.96 & 7.16 & 7.85 & 7.51 \\
\hline \multirow{8}{*}{ LFCR } & $\mathrm{DM}^{4} \%$ & 56.7 & 53.2 & 55.3 & 50.0 \\
\hline & $\mathrm{Ash}_{2}^{5} \%$ of DM & 6.9 & 7.0 & 7.5 & 7.4 \\
\hline & $\mathrm{CP},{ }^{5} \%$ of $\mathrm{DM}$ & 19.4 & 18.1 & 22.3 & 21.0 \\
\hline & Crude fat,,$^{5} \%$ of DM & 2.7 & 2.4 & 3.1 & 2.9 \\
\hline & $\mathrm{NDF},{ }^{5} \%$ of DM & 21.9 & 26.3 & 23.7 & 24.1 \\
\hline & Forage NDF, ${ }^{5} \%$ of total NDF & 79.4 & 82.9 & 81.0 & 81.3 \\
\hline & Sugar ${ }^{6} \%$ of DM & 8.8 & 4.8 & 3.0 & 3.3 \\
\hline & $\mathrm{NE}_{\mathrm{L}},{ }^{7} \mathrm{MJ} / \mathrm{kg}$ of $\mathrm{DM}$ & 8.60 & 8.07 & 8.51 & 8.29 \\
\hline
\end{tabular}

${ }^{1}$ High forage-to-concentrate ratio (80:20; HCFR) and low forage-to-concentrate ratio (50:50; LCFR).

${ }^{2}$ Early spring cut (ESP), late spring cut (LSP), early summer cut (ESU), and late summer cut (LSU).

${ }^{3}$ Concentrate premix HFCR (\% of DM): $48.2 \%$ wheat, $42.4 \%$ soybean meal, $4.8 \%$ minerals, $2.4 \% \mathrm{NaCl}, 1.2 \%$ limestone, $0.48 \%$ vitamins, $0.43 \%$ titanium dioxide. Concentrate premix LFCR (\% of DM): $68.3 \%$ wheat, $27 \%$ soybean meal, $2.0 \%$ minerals, $1.4 \%$ limestone, $1.0 \% \mathrm{NaCl}, 0.2 \%$ vitamins, $0.2 \%$ titanium dioxide.

${ }^{4}$ Mean for DM concentration are for 12 samples composited by period.

${ }^{5}$ Calculated based on chemical composition of individual silages and concentrates.

${ }^{6}$ Calculated based on four composited samples of silages and table values of concentrates.

${ }^{7} \mathrm{NE}_{\mathrm{L}}$ is calculated according to Weisbjerg and Hvelplund (1993).

of ash decreased with increased maturity. In general, all digestibilities were high.

Increased maturity stage decreased the DM concentration of feces. The consistency score was higher in spring cuts at HFCR, whereas no effect of either maturity or season was seen at LFCR.

\section{Forage-to-Concentrate Ratio}

Effect of FCR is shown in Table 6. The FCR did not affect DM or energy intake, whereas NDF intake was higher for HFCR than LFCR. The HFCR increased total chewing time per kilogram of DM. Increased NDF intake was followed by a decreased chewing time per kilogram of NDF. Milk yield measured in kilograms of ECM was not affected by FCR, although a significant effect of FCR $\times$ maturity $\times$ season was seen. The $\mathrm{ECM} / \mathrm{NE}_{\mathrm{L}}$ intake was higher for HFCR than LFCR. The HFCR increased milk fat concentration and decreased lactose concentration. Milk protein concentration was numerically decreased by HFCR resulting in an increased protein:fat ratio with LFCR. The DM con- centration of feces was significantly higher at HFCR, whereas fecal score was not affected by FCR.

\section{DISCUSSION}

\section{Forage Quality and Composition}

The fermentation quality of all silages was high. The ESP had a higher sugar concentration and $\mathrm{pH}$ value than the other cuts, which indicates a restricted fermentation due to a higher DM concentration.

A decrease in forage digestibility and thereby concentration of energy from spring to summer cut and with increased maturity is consistent with findings by Dawson et al. (2002) and Kuoppala et al. (2008). A high proportion of stem in LSP correlated with a higher NDF concentration in silage could explain the lower feeding value of LSP. This is due to changes occurring within the stem and leaves and the rapidly decreasing proportion of leaves, which are more nutritionally valuable than the stem. This results in changes in the nutritional quality of the plants (Terry and Tilley, 1964; 
Table 3. Feed intake, chewing time, and BCS

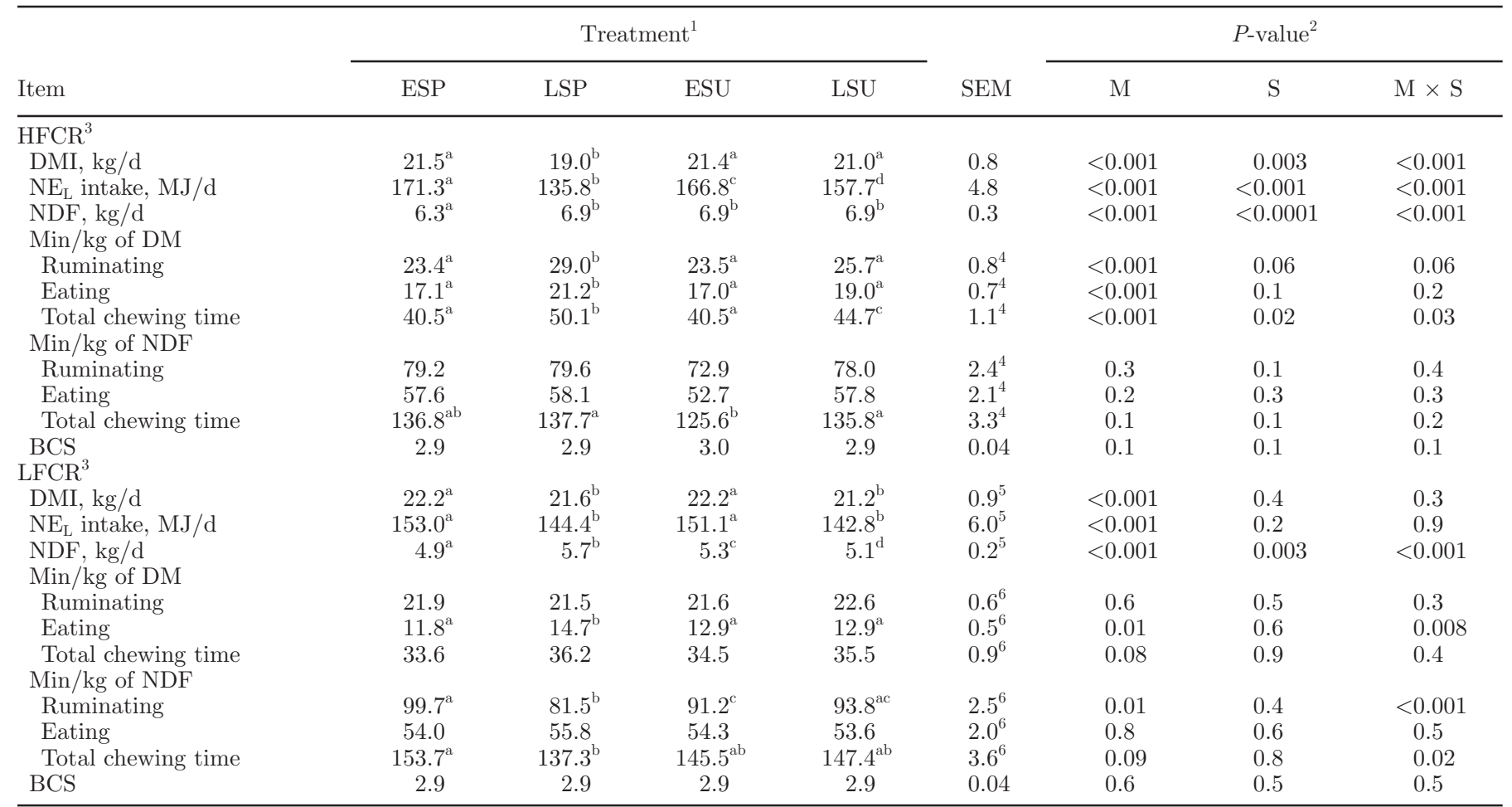

${ }^{\mathrm{a}-\mathrm{d}}$ Means within a row with different superscripts differ $(P<0.05)$.

${ }^{1}$ Early spring cut (ESP), late spring cut (LSP), early summer cut (ESU), and late summer cut (LSU).

${ }^{2} \mathrm{M}=$ main effect of forage maturity, $\mathrm{S}=$ main effect of season, $\mathrm{M} \times \mathrm{S}=$ interaction between maturity of forage and season.

${ }^{3}$ High forage-to-concentrate ratio (80:20; HCFR) and low forage-to-concentrate ratio (50:50; LCFR).

${ }^{4} \mathrm{SEM}$ shown for LSP; SEM for ESP, ESU, and LSU is 1.17, 1.10, and 1.03 greater than LSP, respectively, due to missing observations.

${ }^{5} \mathrm{SEM}$ is 1.0001 times greater for ESP due to 1 omitted cow in period 2.

${ }^{6} \mathrm{SEM}$ shown for LSU; SEM for ESP, LSP, and ESU is 1.10, 1.08, and 1.06 greater than ESU, respectively, due to missing observations.

Rinne, 2000). The CP concentration decreased with increased maturity and increased from spring to summer cuts, which is in accordance with Søegaard (1994) who found that the concentration of $\mathrm{CP}$ increases through the growth season at the same herbage mass. Increased $\mathrm{CP}$ concentration could be explained by a combination of increased clover proportion and increased grass leaf/ stem ratio as the concentration of $\mathrm{CP}$ is higher in clover than in grass leaves, and in grass leaves than grass stem, and the grass stem proportion decreases highly from spring to summer (Søegaard et al., 2003).

\section{$D M I, B W$, and $B C S$}

Increased maturity resulted in decreased DMI as found in other studies (Kuoppala et al., 2008; Kuoppala et al., 2010) probably due to decreased digestibility. Lower intake of rations containing LSP could be explained by higher stem proportion and more lignified stems with higher NDF content resulting in a higher
NDF concentration in silage. Season of harvest also affected DMI, as summer cuts resulted in a higher feed intake than spring cuts. This increase followed increased CP in the ration as also stated by Habib et al. (2006). Effect of season on DMI was diluted by LFCR, which also evened out the differences in concentration of CP between LFCR and HFCR. Overall, increased digestibility of grass-clover silage increased DMI agreeing on the assumption that increased digestibility increases intake potential (Illius and Jessop, 1996).

Response in DMI to FCR was absent, as DMI increased by only $3 \%$ with a $150 \%$ increase in concentrate proportion (from 20 to $50 \%$ ), resulting in a high substitution rate between forage and concentrate of 0.89 and corresponding with findings by Yang et al. (2001). Various other studies (Andersen et al., 2003; Kuoppala et al., 2008; Steinshamn et al., 2008) showed increased DMI with decreased FCR, but high digestible forages in the present experiment diluted this effect. However, for LSP, an increased FCR increased DMI. The NDF intake increased with FCR as expected. 
None of the rations resulted in differences in $\mathrm{BW}$ or BCS. Friggens et al. (1998) found that HFCR gave a higher weight loss than LFCR, whereas the opposite was seen in the present experiment.

\section{Milk Yield and Composition}

Independent of FCR, a higher ECM yield was seen in rations containing early maturity cuts as also found by Kuoppala et al. (2008). This was explained by lower forage digestibility and DMI with increased stage of maturity of grass-clover silages.

For the HFCR rations, greatest milk yields were observed on the ESU treatment. The ECM yield followed to some extent the concentration of $\mathrm{CP}$ in the ration. Previous results of Okine et al. (1997) suggested that a higher milk yield could be induced by a higher CP intake and a slightly higher DMI, and NRC (2001) also concluded that an increased $\mathrm{CP}$ concentration in the ration increased the milk yield. Their results were based on several protein feeding trials and was true until 19\% CP. Leonardi et al. (2003) found no increase in milk yield by increased CP from 16.1 to $18.8 \%$ and neither did Olmos Colmenero and Broderick (2006) from 16.5 to $17.9 \%$ and $19.4 \%$. In the present experiment, all rations exceeded $\mathrm{CP}>16.5 \%$, and it was not expected that the milk yield would be affected by the $\mathrm{CP}$ concentration.

Low-quality silage fed with LFCR had a lower milk yield compared with high-quality silage fed with HFCR, as also indicated by Kristensen and Skovborg (1990) and Kawas et al. (1991). In the current study, a relationship was present between energy intake and milk yield, but not between ration digestibility and milk yield, because the differences in forage digestibilities were not fully mirrored in ration digestibilities. Forage

Table 4. Milk yield and composition

\begin{tabular}{|c|c|c|c|c|c|c|c|c|}
\hline \multirow[b]{2}{*}{ Item } & \multicolumn{4}{|c|}{ Treatment $^{1}$} & \multirow[b]{2}{*}{ SEM } & \multicolumn{3}{|c|}{$P$-value ${ }^{2}$} \\
\hline & $\mathrm{ESP}$ & LSP & ESU & LSU & & M & $\mathrm{S}$ & $\mathrm{M} \times \mathrm{S}$ \\
\hline \multicolumn{9}{|l|}{$\mathrm{HFCR}^{3}$} \\
\hline Milk yield, kg & $30.8^{\mathrm{a}}$ & $26.8^{\mathrm{b}}$ & $31.6^{\mathrm{a}}$ & $31.9^{\mathrm{a}}$ & $1.3^{4}$ & 0.009 & $<0.001$ & 0.003 \\
\hline ECM yield, kg/d & $32.4^{\mathrm{a}}$ & $28.3^{\mathrm{b}}$ & $33.8^{\mathrm{a}}$ & $33.4^{\mathrm{a}}$ & $1.4^{4}$ & 0.01 & $<0.001$ & 0.03 \\
\hline $\mathrm{ECM} / \mathrm{NE}_{\mathrm{L}}, \mathrm{kg} / \mathrm{MJ}$ & $0.19^{\mathrm{a}}$ & $0.21^{\mathrm{b}}$ & $0.20^{\mathrm{b}}$ & $0.21^{\mathrm{b}}$ & 0.01 & 0.005 & 0.05 & 0.3 \\
\hline Protein yield, $\mathrm{kg} / \mathrm{d}$ & $1.07^{\mathrm{a}}$ & $0.89^{\mathrm{b}}$ & $1.07^{\mathrm{a}}$ & $1.03^{\mathrm{a}}$ & 0.04 & $<0.001$ & 0.005 & 0.004 \\
\hline Fat yield, $\mathrm{kg} / \mathrm{d}$ & $1.35^{\mathrm{a}}$ & $1.21^{\mathrm{b}}$ & $1.45^{\mathrm{a}}$ & $1.44^{\mathrm{a}}$ & 0.07 & 0.09 & $<0.001$ & 0.1 \\
\hline Lactose yield, $\mathrm{kg} / \mathrm{d}$ & $1.48^{\mathrm{a}}$ & $1.27^{\mathrm{b}}$ & $1.52^{\mathrm{a}}$ & $1.52^{\mathrm{a}}$ & 0.06 & 0.004 & $<0.001$ & 0.003 \\
\hline Protein, \% & $3.48^{\mathrm{a}}$ & $3.35^{\mathrm{b}}$ & $3.40^{\mathrm{b}}$ & $3.28^{\mathrm{c}}$ & $0.09^{4}$ & $<0.001$ & 0.003 & 0.9 \\
\hline Fat, $\%$ & $4.39^{\mathrm{a}}$ & $4.57^{\mathrm{ab}}$ & $4.60^{\mathrm{b}}$ & $4.52^{\mathrm{ab}}$ & $0.14^{4}$ & 0.5 & 0.3 & 0.08 \\
\hline Protein:fat & $0.80^{\mathrm{a}}$ & $0.74^{\mathrm{b}}$ & $0.75^{\mathrm{b}}$ & $0.73^{\mathrm{b}}$ & $0.02^{4}$ & 0.002 & 0.03 & 0.09 \\
\hline Lactose, $\%$ & $4.81^{\mathrm{a}}$ & $4.75^{\mathrm{b}}$ & $4.81^{\mathrm{a}}$ & $4.78^{\mathrm{ab}}$ & $0.59^{4}$ & 0.02 & 0.3 & 0.5 \\
\hline Urea, $\mathrm{m} M$ & $5.94^{\mathrm{a}}$ & $5.46^{\mathrm{b}}$ & $9.30^{\mathrm{c}}$ & $8.64^{\mathrm{d}}$ & $0.20^{5}$ & $<0.001$ & $<0.001$ & 0.5 \\
\hline $\mathrm{BHB}, \mathrm{m} M$ & $57.16^{\mathrm{a}}$ & $65.77^{\mathrm{b}}$ & $54.10^{\mathrm{a}}$ & $61.68^{\mathrm{ab}}$ & $3.92^{5}$ & 0.01 & 0.3 & 0.9 \\
\hline Uric acid, $\mu M$ & 96.32 & 110.78 & 97.32 & 116.20 & $10.46^{5}$ & 0.08 & 0.7 & 0.8 \\
\hline \multicolumn{9}{|l|}{$\mathrm{LFCR}^{3}$} \\
\hline Milk yield, kg & $32.1^{\mathrm{a}}$ & $29.7^{\mathrm{b}}$ & $32.7^{\mathrm{a}}$ & $31.7^{\mathrm{a}}$ & $1.3^{6}$ & 0.002 & 0.01 & 0.2 \\
\hline ECM yield, kg/d & $33.1^{\mathrm{ab}}$ & $31.7^{\mathrm{a}}$ & $33.5^{\mathrm{b}}$ & $32.7^{\mathrm{ab}}$ & $1.1^{6}$ & 0.04 & 0.2 & 0.6 \\
\hline $\mathrm{ECM} / \mathrm{NE}_{\mathrm{L}}, \mathrm{kg} / \mathrm{MJ}$ & $0.17^{\mathrm{a}}$ & $0.18^{\mathrm{bc}}$ & $0.18^{\mathrm{b}}$ & $0.19^{\mathrm{c}}$ & $0.002^{7}$ & $<0.001$ & 0.04 & 0.8 \\
\hline Protein yield, $\mathrm{kg} / \mathrm{d}$ & $1.22^{\mathrm{a}}$ & $1.11^{\mathrm{b}}$ & $1.22^{\mathrm{a}}$ & $1.17^{\mathrm{a}}$ & 0.04 & $<0.001$ & 0.08 & 0.1 \\
\hline Fat yield, kg/d & 1.28 & 1.28 & 1.29 & 1.27 & 0.05 & 0.8 & 0.8 & 0.7 \\
\hline Lactose yield, $\mathrm{kg} / \mathrm{d}$ & $1.59^{\mathrm{a}}$ & $1.47^{\mathrm{b}}$ & $1.63^{\mathrm{a}}$ & $1.58^{\mathrm{a}}$ & 0.07 & 0.002 & 0.006 & 0.2 \\
\hline Protein, $\%$ & $3.81^{\mathrm{a}}$ & $3.75^{\mathrm{ab}}$ & $3.75^{\mathrm{ab}}$ & $3.72^{\mathrm{b}}$ & $0.07^{6}$ & 0.08 & 0.2 & 0.5 \\
\hline Fat, $\%$ & $4.00^{\mathrm{a}}$ & $4.35^{\mathrm{b}}$ & $3.98^{\mathrm{a}}$ & $4.05^{\mathrm{a}}$ & $0.16^{6}$ & 0.004 & 0.03 & 0.05 \\
\hline Protein:fat & $0.98^{\mathrm{a}}$ & $0.88^{\mathrm{b}}$ & $0.96^{\mathrm{a}}$ & $0.94^{\mathrm{a}}$ & $0.04^{6}$ & $<0.001$ & 0.1 & 0.02 \\
\hline Lactose, \% & $4.96^{\mathrm{ab}}$ & $4.94^{\mathrm{a}}$ & $4.98^{\mathrm{b}}$ & $4.97^{\mathrm{ab}}$ & $0.04^{6}$ & 0.2 & 0.03 & 0.1 \\
\hline Urea, $\mathrm{m} M$ & $6.27^{\mathrm{a}}$ & $6.23^{\mathrm{a}}$ & $8.14^{\mathrm{b}}$ & $7.56^{\mathrm{b}}$ & $0.26^{8}$ & 0.1 & $<0.001$ & 0.2 \\
\hline $\mathrm{BHB}, \mathrm{m} M$ & 59.20 & 55.09 & 48.13 & 46.50 & $5.40^{8}$ & 0.6 & 0.05 & 0.8 \\
\hline Uric acid, $\mu M$ & 129.10 & 126.83 & 135.59 & 131.81 & $9.75^{8}$ & 0.7 & 0.5 & 0.9 \\
\hline
\end{tabular}

\footnotetext{
${ }^{\mathrm{a}-\mathrm{d}}$ Means within a row with different superscripts differ $(P<0.05)$.

${ }^{1}$ Early spring cut (ESP), late spring cut (LSP), early summer cut (ESU), and late summer cut (LSU).

${ }^{2} \mathrm{M}=$ main effect of forage maturity, $\mathrm{S}=$ main effect of season, $\mathrm{M} \times \mathrm{S}=$ interaction between maturity of forage and season.

${ }^{3}$ High forage-to-concentrate ratio (80:20; HCFR) and low forage-to-concentrate ratio (50:50; LCFR).

${ }^{4} \mathrm{SEM}$ for summer cuts is 1.0009 greater due to omitted observations.

${ }^{5}$ SEM shown for ESP; SEM for LSP, ESU, and LSU is 1.03, 1.03, and 1.08 greater, respectively, due to omitted observations.

${ }^{6} \mathrm{SEM}$ shown for LSP and ESU; SEM for ESP and LSU is 1.01 and 1.0001 greater, respectively, due to omitted observations.

${ }^{7} \mathrm{SEM}$ for ESP is 1.06 greater than SEM shown due to omitted observations.

${ }^{8} \mathrm{SEM}$ for LSU is 1.01 greater than SEM shown due to omitted observations.
} 
digestibilities affected DMI and thereby probably the passage rate. Therefore, the differences in digestibilities of rations were partly evened out. Even though ESU resulted in the numerically highest milk yield, having a lower digestibility than ESP, no significant difference was found in milk yield between the 2 cuts.

Composition of milk was affected by both maturity and season. The spring cut tended to result in a higher milk protein concentration and agreed with findings of Kuoppala et al. (2008). A high milk protein concentration has been related to high digestible silages and may be reflected in an improved energy status and increased intestinal supply of AA to the cow (Rinne et al., 1999). Increased maturity tended to increase the milk fat concentration, and this was opposite to findings by Kuoppala et al. (2008). Rinne et al. (1999) stated that effects of maturity of grass for silage on the milk fat concentration in general are variable. An explanation may be inconsistency in effects of grass maturity on the fermentation in rumen (Rinne et al., 1999). The urea concentration in milk followed the $\mathrm{CP}$ concentration in the rations as also found by Groff and Wu (2005). Uric acid concentration in the milk was not affected by maturity and season; however, uric acid concentration was higher for LFCR than for HFCR, indicating a higher rumen microbial synthesis for LFCR, and higher uric acid concentration might improve the antioxidative capacity of milk (Østdal et al., 2008).

Response of ECM yield to FCR was absent. However, it was possible to increase the ECM yield with $3.4 \mathrm{~kg} / \mathrm{d}$ on HFCR versus LFCR for LSP forage. Various studies have shown different results according to effect of
FCR on milk production. Llamas-Lamas and Combs (1990) showed no effect on the actual milk yield or FCM production by decreased FCR (68 to $45 \%$ alfalfa forage). However, maturity of alfalfa was confounded with changed FCR in this study. Yang et al. (2001) and Hymøller et al. (2014) did not find any effects on FCM or ECM yields of FCR (65 vs. $45 \%$ and 70 vs. $60 \%$ ) either. On the other hand, Dewhurst et al. (2002), Andersen et al. (2003), and Kuoppala et al. (2008) found that decreased FCR increased the milk yield. Jensen (2014) showed that an increased $\mathrm{NE}_{\mathrm{L}}$ intake is often diverted into body tissues at higher intakes, particularly in the last part of lactation, causing diminished returns.

Higher $\mathrm{ECM} / \mathrm{NE}_{\mathrm{L}}$ was found for HFCR than for LFCR, indicating a lower feed efficiency as a consequence of decreased digestion of fibers. Decreased fiber digestibility on LFCR could be explained by a faster passage rate and concentrate inhibiting fermentation of fiber fractions in the rumen either due to substrate preference or due to reduced rumen $\mathrm{pH}$. De Brabander et al. (1999) mentioned the necessity of feeding rations with low FCR to high-producing cows to meet their demand of energy, especially in early lactation. This large amount of concentrates should be combined with high-quality forages. According to our results, goodquality forage tends to dilute the positive effect of an increased concentrate proportion on the ECM yield as also found in Hymøller et al. (2014). Forage digestibility has also been found to affect methane production, as decreased forage maturity decreased methane emission probably due to decreased feed intake and thereby decreased fermentable matter available (Boadi and

Table 5. Ration digestibilities and fecal DM concentration and consistency score

\begin{tabular}{|c|c|c|c|c|c|c|c|c|}
\hline \multirow[b]{2}{*}{ Item } & \multicolumn{4}{|c|}{ Treatment $^{1}$} & \multirow[b]{2}{*}{$\mathrm{SEM}^{2}$} & \multicolumn{3}{|c|}{$P$-value ${ }^{3}$} \\
\hline & $\mathrm{ESP}$ & LSP & $\mathrm{ESU}$ & LSU & & M & $\mathrm{S}$ & $\mathrm{M} \times \mathrm{S}$ \\
\hline \multicolumn{9}{|l|}{$\mathrm{HFCR}^{4}$} \\
\hline DM digestibility, \% & $77.2^{\mathrm{a}}$ & $77.2^{\mathrm{a}}$ & $78.9^{\mathrm{b}}$ & $76.8^{\mathrm{a}}$ & 0.01 & 0.04 & 0.2 & 0.03 \\
\hline Ash digestibility, \% & $62.0^{\mathrm{a}}$ & $65.6^{\mathrm{b}}$ & $68.1^{\mathrm{c}}$ & $63.2^{\mathrm{a}}$ & 0.01 & 0.4 & 0.02 & $<0.001$ \\
\hline OM digestibility, \% & $78.5^{\mathrm{a}}$ & $78.3^{\mathrm{a}}$ & $79.9^{\mathrm{b}}$ & $78.0^{\mathrm{a}}$ & 0.01 & 0.04 & 0.2 & 0.1 \\
\hline NDF digestibility, \% & $70.2^{\mathrm{a}}$ & $70.1^{\mathrm{a}}$ & $76.0^{\mathrm{b}}$ & $72.4^{\mathrm{a}}$ & 0.01 & 0.1 & 0.001 & 0.1 \\
\hline Fecal DM, \% & $13.0^{\mathrm{a}}$ & $12.0^{\mathrm{b}}$ & $12.4^{\mathrm{ab}}$ & $12.0^{\mathrm{b}}$ & 0.3 & 0.01 & 0.4 & 0.3 \\
\hline Fecal score $(1-5)$ & $3.2^{\mathrm{ab}}$ & $3.3^{\mathrm{b}}$ & $3.0^{\mathrm{a}}$ & $3.0^{\mathrm{a}}$ & 0.1 & 0.3 & 0.01 & 0.4 \\
\hline \multicolumn{9}{|l|}{$\mathrm{LFCR}^{4}$} \\
\hline DM digestibility, \% & $77.9^{\mathrm{a}}$ & $75.4^{\mathrm{b}}$ & $77.6^{\mathrm{a}}$ & $75.1^{\mathrm{b}}$ & 0.01 & $<0.001$ & 0.7 & 0.9 \\
\hline Ash digestibility, \% & $53.7^{\mathrm{a}}$ & $48.7^{\mathrm{b}}$ & $57.2^{\mathrm{a}}$ & $49.6^{\mathrm{b}}$ & 0.01 & $<0.001$ & 0.08 & 0.3 \\
\hline OM digestibility, \% & $79.3^{\mathrm{a}}$ & $77.1^{\mathrm{b}}$ & $79.0^{\mathrm{a}}$ & $76.7^{\mathrm{b}}$ & 0.01 & 0.002 & 0.6 & 1 \\
\hline NDF digestibility, $\%$ & $60.0^{\mathrm{ab}}$ & $58.6^{\mathrm{ab}}$ & $62.5^{\mathrm{a}}$ & $56.9^{\mathrm{b}}$ & 0.02 & 0.07 & 0.8 & 0.3 \\
\hline Fecal DM, \% & $13.9^{\mathrm{ac}}$ & $12.6^{\mathrm{b}}$ & $14.2^{\mathrm{c}}$ & $13.3^{\mathrm{a}}$ & $0.2^{4}$ & $<0.001$ & 0.01 & 0.5 \\
\hline Fecal score $(1-5)$ & 3.1 & 3.1 & 3.3 & 3.1 & $0.1^{4}$ & 0.6 & 0.4 & 0.3 \\
\hline
\end{tabular}

\footnotetext{
${ }^{a-c}$ Means within a row with different superscripts differ $(P<0.05)$.

${ }^{1}$ Early spring cut (ESP), late spring cut (LSP), early summer cut (ESU), and late summer cut (LSU).

${ }^{2} \mathrm{SEM}$ for ESP is 1.07 greater than SEM shown due to omitted observations.

${ }^{3} \mathrm{M}=$ main effect of forage maturity, $\mathrm{S}=$ main effect of season, $\mathrm{M} \times \mathrm{S}=$ interaction between maturity of forage and season.

${ }^{4}$ High forage-to-concentrate ratio (80:20; HCFR) and low forage-to-concentrate ratio (50:50; LCFR).
} 
Wittenberg, 2002). Brask et al. (2013) found that total daily methane production did not differ between early and late maturity grasses; however, as DMI decreased with increased stage of maturity, methane expressed per kilogram of DMI and energy intake increased with increased stage of maturity. On the other hand, Hellwing and Weisbjerg (2010) did not find any effect of forage digestibilities on methane production. Brask et al. (2013) suggested that if a late maturity grass is used, it should be combined with LFCR.

The LFCR increased milk protein and lactose concentration, and a tendency toward the same patterns was found by Kuoppala et al. (2008). The positive effect of LFCR on milk protein concentration was probably due to increased intake of energy as also stated by Keady et al. (2008). The LFCR decreased milk fat concentration in accordance with other findings (Sutton, 1989; Weiss and Shockey, 1991; Kuoppala et al., 2008). A review suggests that concentration of milk fat is fairly stable until a proportion of concentrate beyond 50\% (Sutton, 1989), which agrees with findings in the present experiment. Decreased milk fat concentration is often accompanied by decreased milk fat yield and increased energy retention or BW (Sutton, 1989).

\section{Chewing Activity}

Increased maturity resulted in longer chewing time, and this is consistent with findings by De Boever et al. (1993) and Schulze et al. (2014). These higher chewing

Table 6. Effect of forage-to-concentrate ratio on all production parameters ${ }^{1}$

\begin{tabular}{|c|c|c|c|c|}
\hline Production parameter & $\mathrm{HFCR}^{2}$ & $\mathrm{LFCR}^{2}$ & SEM & $P$-value \\
\hline \multicolumn{5}{|l|}{ Feed intake ${ }^{3,4}$} \\
\hline DMI, kg/d & 20.9 & 21.6 & 0.8 & 0.6 \\
\hline $\mathrm{NE}_{\mathrm{L}}$ intake, MJ/d & 159.9 & 180.4 & 5.4 & 0.07 \\
\hline $\mathrm{NDF}, \mathrm{kg} / \mathrm{d}$ & 6.8 & 5.2 & 0.2 & 0.007 \\
\hline \multicolumn{5}{|l|}{ Chewing activity ${ }^{4,5}$} \\
\hline Ruminating, min/kg of DM & 24.7 & 22.2 & 0.5 & $<0.001$ \\
\hline Eating, min/kg of DM & 17.9 & 13.4 & 0.5 & $<0.001$ \\
\hline Total chewing time, $\mathrm{min} / \mathrm{kg}$ of DM & 42.6 & 35.5 & 0.7 & $<0.001$ \\
\hline Ruminating, $\min / \mathrm{kg}$ of $\mathrm{NDF}$ & 75.2 & 92.5 & 1.8 & $<0.001$ \\
\hline Eating, $\min / \mathrm{kg}$ of $\mathrm{NDF}$ & 54.4 & 55.6 & 1.8 & 0.6 \\
\hline Total chewing time, $\mathrm{min} / \mathrm{kg}$ of NDF & 129.5 & 148.1 & 2.7 & $<0.001$ \\
\hline \multicolumn{5}{|l|}{ Milk production 6} \\
\hline ECM yield, kg/d & 32.1 & 32.6 & $1.4^{7}$ & 0.8 \\
\hline $\mathrm{ECM} / \mathrm{NE}_{\mathrm{L}}, \mathrm{kg} / \mathrm{MJ}$ & 0.20 & 0.18 & $0.002^{8}$ & $<0.001$ \\
\hline Protein yield, $\mathrm{kg} / \mathrm{d}$ & 1.02 & 1.17 & 0.04 & 0.07 \\
\hline Fat yield, $\mathrm{kg} / \mathrm{d}$ & 1.37 & 1.27 & 0.06 & 0.3 \\
\hline Lactose yield, $\mathrm{kg} / \mathrm{d}$ & 1.46 & 1.56 & 0.07 & 0.4 \\
\hline Protein, $\%$ & 3.38 & 3.76 & $0.01^{7}$ & 0.05 \\
\hline Fat, $\%$ & 4.52 & 4.10 & $0.14^{7}$ & 0.04 \\
\hline Protein:fat & 0.76 & 0.94 & $0.03^{7}$ & $<0.001$ \\
\hline Lactose, \% & 4.79 & 4.96 & $0.05^{7}$ & 0.02 \\
\hline Urea, $\mathrm{m} M$ & 7.0 & 7.1 & $0.2^{8}$ & 0.9 \\
\hline $\mathrm{BHB}, \mathrm{m} M$ & 57.34 & 48.94 & $3.5^{8}$ & 0.2 \\
\hline Uric acid, $\mu M$ & 101.0 & 129.4 & $7.6^{8}$ & 0.02 \\
\hline \multicolumn{5}{|l|}{ Ration digestibility } \\
\hline DM digestibility, \% & 77.5 & 76.5 & $0.7^{9}$ & 0.3 \\
\hline Ash digestibility, $\%$ & 64.7 & 52.3 & $0.9^{9}$ & $<0.001$ \\
\hline OM digestibility, \% & 78.7 & 78.0 & $0.6^{9}$ & 0.5 \\
\hline NDF digestibility, \% & 72.2 & 59.4 & $1.5^{9}$ & 0.004 \\
\hline \multicolumn{5}{|l|}{ Feces $^{10}$} \\
\hline DM, \% & 12.3 & 13.5 & $0.1^{9}$ & $<0.001$ \\
\hline Score $(1-5)$ & 3.12 & 3.13 & $0.04^{9}$ & 0.9 \\
\hline
\end{tabular}

${ }^{1}$ Overview across experiments with measurements in week before experiments start used as covariates in analysis.

${ }^{2}$ High forage-to-concentrate ratio (80:20; HCFR) and low forage-to-concentrate ratio (50:50; LCFR).

${ }^{3} \mathrm{SEM}$ for LFCR is 1.009 greater due to omitted observations.

${ }^{4} \mathrm{DMI}$ from pre-period used as covariate.

${ }^{5} \mathrm{SEM}$ for LFCR is 1.003 greater due to omitted observations.

${ }^{6} \mathrm{ECM}$ from pre-period used as covariate.

${ }^{7} \mathrm{SEM}$ for LFCR is 1.002 greater due to omitted observations.

${ }^{8} \mathrm{SEM}$ for LFCR is 1.005 greater due to omitted observations.

${ }^{9} \mathrm{SEM}$ for LFCR is 1.02 greater due to omitted observations.

${ }^{10}$ No covariate used. 
indexes for silages from grasses of later growth are due to aging, where the composition of grass shifts to more lignified cell walls. Forage NDF has a slow digestion rate in the rumen relative to other feed constituents such as proteins, starches, and so on. However, the concentration of cell walls is not the only factor affecting chewing activity; resistance to comminution also has an effect (De Boever et al., 1993).

Time of rumination reflected that although ESP had a lower NDF concentration than the other cuts, the structural value was similar to that of the other 3 cuts in promoting rumination. Across FCR, the LSP resulted in the longest numerical total chewing time per kilogram of DM. This was expected according to a higher concentration of stem and NDF and a lower forage digestibility. Chewing time measured per kilogram of DM was found to be the best indicator of structural value, as total chewing time per kilogram of DM increased when the concentration of NDF in the ration increased. Even though the NDF concentration of ESP, ESU, and LSU at LFCR was beyond the recommended minimum concentration of dietary NDF (\% of DM) of $25 \%$ (NRC, 2001), all rations fulfilled the recommended minimum forage NDF of total NDF of $75 \%$ (NRC, 2001). Chewing time per kilogram of NDF decreased when intake of NDF increased as also found by Schulze et al. (2014) and may be explained by more efficient chewing or simply a dilution of available time for chewing on the feed.

\section{Feces}

A higher DM concentration in feces was found to be induced both by increased digestibility caused by LFCR and by higher digestibility induced by the higher digestible silages. Møller et al. (2014) showed a numerical decrease in fecal DM with increased stage of maturity of grass silage. Higher CP concentration in especially ESU did not seem to affect the consistency negatively, as feces did not appear liquid as a result of a high $\mathrm{CP}$ level, and the feces DM concentration was even the highest on these protein-rich treatment rations. Ireland-Perry and Stallings (1993) stated that the protein source rather than the protein level affects the fecal consistency.

Ireland-Perry and Stallings (1993) suggested that a higher DM concentration in LFCR (17\% ADF) could have been composed by more nonfiber components such as escaped dietary starch and a greater proportion of microbial matter due to higher hindgut fermentation. They explained a lower DM concentration and a higher fecal score for HFCR (25\% ADF) by a greater proportion of fiber, assuming that fibrous material has a high water-holding capacity (Ireland-Perry and Stallings, 1993).

The fecal DM seemed to decrease when DMI decreased. Liquid feces may be a determinant of a ration with inadequate structural value. As none of the fecal samples were categorized as liquid, either based on DM concentration or score, this establishes the conclusion that all rations contained adequate structural value at least concerning fecal score.

\section{CONCLUSIONS}

Digestibility of rations induced both by lower FCR and by higher digestible forage increased DMI and, to a certain level, the ECM yield. Adequate physical structure was obtained for all rations, suggesting that it is possible to sustain the physical structural value even when feeding very high digestible forages. Increased maturity and increased forage:concentrate ratio decreased fecal DM concentration. Digestibility of rations was found to be positively correlated with fecal DM concentration. This study indicates that summer cuts have a milk production value equal to spring cuts when digestibility is taken into account.

\section{ACKNOWLEDGMENTS}

The work was funded by Mælkeafgiftfonden (Milk Levy Fund, Denmark). The authors express their appreciation to the staff in the barn for their committed work.

\section{REFERENCES}

Åkerlind, M., M. Weisbjerg, T. Eriksson, R. Thøgersen, P. Udén, B. L. Ólafsson, O. M. Harstad, and H. Volden. 2011. Feed analyses and digestion methods. Pages 41-54 in NorFor-The Nordic feed evaluation system. H. Volden, ed. EAAP publication no. 130. Wageningen Academic Publishers, Wageningen, the Netherlands.

Allen, M. S. 2000. Effects of diet on short-term regulation of feed intake by lactating dairy cattle. J. Dairy Sci. 83:1598-1624.

Andersen, J. B., N. C. Friggens, K. Sejrsen, M. T. Sørensen, L. Munksgaard, and K. L. Ingvartsen. 2003. The effects of low vs. high concentrate level in the diet on performance in cows milked two or three times daily in early lactation. Livest. Prod. Sci. 81:119-128.

AOAC International. 2000. Official Methods of Analysis. 15th ed. AOAC Int., Washington, DC.

Beauchemin, K. A., and W. Z. Yang. 2005. Effects of physically effective fiber on intake, chewing activity, and ruminal acidosis for dairy cows fed diets based on corn silage. J. Dairy Sci. 88:2117-2129.

Boadi, D., and K. M. Wittenberg. 2002. Methane production from dairy and beef heifers fed forages differing in nutrient density using the sulphur hexafluoride (SF6) tracer gas technique. Can. J. Anim. Sci. 82:201-206.

Brask, M., P. Lund, A. L. F. Hellwing, M. Poulsen, and M. R. Weisbjerg. 2013. Enteric methane production, digestibility and rumen fermentation in dairy cows fed different forages with and without rapeseed fat supplementation. Anim. Feed Sci. Technol. 184:67-79.

Dawson, L. E. R., R. M. Kirkland, C. P. Ferris, R. W. J. Steen, D. J. Kilpatrick, and F. J. Gordon. 2002. The effect of stage of perennial 
ryegrass maturity at harvesting, fermentation characteristics and concentrate supplementation, on the quality and intake of grass silage by beef cattle. Grass Forage Sci. 57:255-267.

De Boever, J. L., A. De Smet, D. L. De Brabander, and C. V. Boucque. 1993. Evaluation of physical structure. 1. Grass silage. J. Dairy Sci. 76:140-153.

De Brabander, D. L., J. L. De Boever, A. M. De Smet, J. M. Vanacker, and C. V. Boucqué. 1999. Evaluation of the physical structure of fodder beets, potatoes, pressed beet pulp, brewers grains and Corn Cob Silage. J. Dairy Sci. 82:110-121.

Dewhurst, R. J., J. M. Moorby, M. S. Dhanoa, and W. J. Fisher. 2002. Effects of level of concentrate feeding during the second gestation of Holstein-Friesian dairy cows. 1. Feed Intake and milk production. J. Dairy Sci. 85:169-177.

Ferguson, J. D., D. T. Galligan, and N. Thomsen. 1994. Principal descriptors of body condition score in Holstein cows. J. Dairy Sci. 77:2695-2703.

Friggens, N. C., G. C. Emmans, I. Kyriazakis, J. D. Oldham, and M. Lewis. 1998. Feed intake relative to stage of lactation for dairy cows consuming total mixed diets with a high or low ratio of concentrate to forage. J. Dairy Sci. 81:2228-2239.

Groff, E. B., and Z. Wu. 2005. Milk production and nitrogen excretion of dairy cows fed different amounts of protein and varying proportions of alfalfa and corn silage. J. Dairy Sci. 88:3619-3632.

Habib, M., J. S. Syed, and J. D. Leaver. 2006. Choice of grass or maize silages by lactating dairy cows: Influence of supplementary protein, concentrate level and milk yield. Anim. Sci. 82:469-477.

Hansen, B. 1989. Determination of nitrogen as elementary-N, an alternative to Kjeldahl. Acta Agric. Scand. 39:113-118.

Hellwing, A. L. F., and M. R. Weisbjerg. 2010. Effect of digestibility of grass-clover silage and concentrate to forage ratio on methane emission from dairy cows. Pages 120-121 in Proc. 4th Int. Conf. Greenhouse Gases and Animal Agriculture. E. J. Mc Geough and S. M. McGinn, ed. Banff, Canada.

Huhtanen, P., M. Rinne, and J. Nousiainen. 2007. Evaluation of the factors affecting silage intake of dairy cows: A revision of the relative silage dry-matter intake index. Animal 1:758-770.

Hymøller, L., L. Alstrup, M. K. Larsen, P. Lund, and M. R. Weisbjerg. 2014. High-quality forage can replace concentrate when cows enter the deposition phase without negative consequences for milk production. J. Dairy Sci. 97:4433-4443.

Illius, A. W., and N. S. Jessop. 1996. Metabolic constraints on voluntary intake in ruminants. J. Anim. Sci. 74:3052-3062.

Ireland-Perry, R. L., and C. C. Stallings. 1993. Fecal consistency as related to dietary composition in lactating Holstein cows. J. Dairy Sci. 76:1074-1082.

Jensen, C. 2014. Milk and growth responses to energy intake in dairy cattle - in the perspective of the non-additive feed evaluation system - NorFor. Ph.D. thesis. Science and Technology, Aarhus University. $105 \mathrm{pp}$.

Kawas, J. R., N. A. Jorgensen, and J. L. Danelon. 1991. Fiber requirements of dairy cows: Optimum fiber level in lucerne-based diets for high producing cows. Livest. Prod. Sci. 28:107-119.

Keady, T. W. J., D. J. Kilpatrick, C. S. Mayne, and F. J. Gordon. 2008. Effects of replacing grass silage with maize silages, differing in maturity, on performance and potential concentrate sparing effect of dairy cows offered two feed value grass silages. Livest. Sci. 119:1-11.

Knudsen, K. E. B., P. Åman, and B. O. Eggum. 1987. Nutritive value of Danish-grown barley varieties, I, carbohydrates and other major constituents. J. Cereal Sci. 6:173-186.

Kristensen, N. B., K. H. Sloth, O. Højberg, N. H. Spliid, C. Jensen, and R. Thøgersen. 2010. Effects of microbial inoculants on corn silage fermentation, microbial contents, aerobic stability, and milk production under field conditions. J. Dairy Sci. 93:3764-3774.

Kristensen, N. B., A. Storm, B. M. L. Raun, B. A. Røjen, and D. L. Harmon. 2007. Metabolism of silage alcohols in lactating dairy cows. J. Dairy Sci. 90:1364-1377.

Kristensen, T., C. Jensen, S. Østergaard, M. R. Weisbjerg, O. Aaes, and N. I. Nielsen. 2015. Feeding, production, and efficiency of
Holstein-Friesian, Jersey, and mixed-breed lactating dairy cows in commercial Danish herds. J. Dairy Sci. 98:263-274.

Kristensen, V. F., and E. B. Skovborg. 1990. Betydningen af tidspunktet for 1 . slæt i græs for græsudbytte og-kvalitet og for ensilageoptagelse og produktion hos malkekøer. Fællesberetning nr. 15. Landbrugsministeriet. Fællesudvalget for Statens Planteavls- og Husdyrbrugsfors $\emptyset$ g.

Kuoppala, K., M. Rinne, S. Ahvenjärvi, J. Nousiainen, and P. Huhtanen. 2010. The effect of harvesting strategy of grass silage on digestion and nutrient supply in dairy cows. J. Dairy Sci. 93:3253-3263.

Kuoppala, K., M. Rinne, J. Nousiainen, and P. Huhtanen. 2008. The effect of cutting time of grass silage in primary growth and regrowth and the interactions between silage quality and concentrate level on milk production of dairy cows. Livest. Sci. 116:171-182.

Larsen, T., and K. M. Moyes. 2010. Fluorometric determination of uric acid in bovine milk. J. Dairy Res. 77:438-444.

Larsen, T., and N. I. Nielsen. 2005. Fluorometric determination of $\beta$-hydroxybutyrate in milk and blood plasma. J. Dairy Sci. 88:2004-2009.

Leonardi, C., M. Stevenson, and E. Armentano. 2003. Effect of two levels of crude protein and methionine supplementation on performance of dairy cows. J. Dairy Sci. 86:4033-4042.

Llamas-Lamas, G., and D. K. Combs. 1990. Effect of alfalfa maturity on fiber utilization by high producing dairy cows. J. Dairy Sci. 73:1069-1080.

Mertens, D. R. 1997. Creating a system for meeting the fiber requirements of dairy cows. J. Dairy Sci. 80:1463-1481.

Mertens, D. R. 2002. Gravimetric determination of amylase-treated neutral detergent fiber in feeds with refluxing in beakers or crucibles: Collaborative study. J. AOAC Int. 85:1217-1240.

Møller, H. B., V. Moset, M. Brask, M. R. Weisbjerg, and P. Lund. 2014. Feces composition and manure derived methane yield from dairy cows: Influence of diet with focus on fat supplement and roughage type. Atmos. Environ. 94:36-43.

Nielsen, N. I., T. Larsen, M. Bjerring, and K. L. Ingvartsen. 2005. Quarter health, milking interval, and sampling time during milking affect the concentration of milk constituents. J. Dairy Sci. 88:3186-3200.

Nielsen, T. S., N. B. Kristensen, and M. R. Weisbjerg. 2007. Effect of harvest time on fermentation profiles of maize ensiled in laboratory silos and determination of drying losses at $60^{\circ} \mathrm{C}$. Acta Agric. Scand. A 57:30-37.

NRC. 2001. Nutrient Requirements of Dairy Cattle. 7th rev. ed., Natl. Acad. Press, Washington, DC.

Oba, M., and M. S. Allen. 1999. Evaluation of the importance of the digestibility of neutral detergent fiber from forage: Effects on dry matter intake and milk yield of dairy cows. J. Dairy Sci. 82:589596.

Okine, E. K., G. R. Khorasani, and J. J. Kennelly. 1997. Effects of source of forage and level of concentrate on chewing activity and milk production response in late lactation cows. Can. J. Anim. Sci. $77: 253-258$

Olmos Colmenero, J. J., and G. A. Broderick. 2006. Effect of dietary crude protein concentration on milk production and nitrogen utilization in lactating dairy cows. J. Dairy Sci. 89:1704-1712.

Østdal, H., M. R. Weisbjerg, L. Skibsted, and J. H. Nielsen. 2008. Protection against photooxidation of milk by high urate content. Milchwissenschaft 63:119-122.

Randby, Å. T., P. Nørgaard, and M. R. Weisbjerg. 2010. Effect of increasing plant maturity in timothy-dominated grass silage on the performance of growing/finishing Norwegian Red bulls. Grass Forage Sci. 65:273-286.

Randby, Å. T., M. R. Weisbjerg, P. Nørgaard, and B. Heringstad. 2012. Early lactation feed intake and milk yield responses of dairy cows offered grass silages harvested at early maturity stages. J. Dairy Sci. 95:304-317.

Rinne, M. 2000. Influence of the timing of the harvest of primary grass growth on herbage quality and subsequent digestion and performance in the ruminant animal. Academic Dissertation. University 
of Helsinki, Faculty of Agricultural Forestry, Department of Animal Sci., Publications 54.

Rinne, M., S. Jaakkola, K. Kaustell, T. Heikkilä, and P. Huhtanen. 1999. Silages harvested at different stages of grass growth $v$. concentrate foods as energy and protein sources in milk production. Anim. Sci. 69:251-263.

Rutter, S. M. 2000. Graze: A program to analyze recordings of the jaw movements of ruminants. Behav. Res. Methods Instrum. Comput. $32: 86-92$.

Schoorl, N. 1929. Suiker-titratie (Sugar titration). Chem. Weekbl. $26: 130-134$.

Schulze, A. K. S., M. R. Weisbjerg, and P. Nørgaard. 2014. Effects of feeding level and NDF content of grass-clover silages on chewing activity, fecal particle size and NDF digestibility in dairy heifers. Animal 8:1945-1954.

Sjaunja, L. O., L. Baevre, L. Junkkarinen, J. Pedersen, and J. Setala. 1991. A Nordic proposal for an energy corrected milk (ECM) formula. Performance recording of animals: State of the art 1990. EAAP Publication 50:156-157.

Søegaard, K. 1994. Kombinationer af slæt og afgræsning i græs og kløvergræs. Kvalitet og kvalitetsstyring. SP Rapport nr. 4. Statens Planteavlsfors $\varnothing \mathrm{g}$. Landbrugsministeriet.

Søegaard, K., H. Hansen, and M. R. Weisbjerg. 2003. Fodermidlernes karakteristika. T. Hvelplund, and P. Nørgaard, ed. Pages 489-510 in Kvægets ernæring og fysiologi. Bind 1-Næringsstofomsætning og fodervurdering. DJF rapport Husdyrbrug nr. 53. Danmarks JordbrugsForskning. Ministeriet for Fødevarer, Landbrug og Fiskeri.

Steinshamn, H., S. Purup, E. Thuen, and J. Hansen-Møller. 2008. Effects of clover-grass silages and concentrate supplementation on the content of phytoestrogens in dairy cow milk. J. Dairy Sci 91:2715-2725.

Steinshamn, H., and E. Thuen. 2008. White or red clover-grass silage in organic dairy milk production: Grassland productivity and milk production responses with different levels of concentrate. Livest. Sci. 119:202-215.

Stoldt, W. 1952. Vorschlag zur vereinheitlichung der fettbestimmung in lebensmitteln. Fette und Seifen 54:206-207.

Sutton, J. D. 1989. Altering milk composition by feeding. J. Dairy Sci 72:2801-2814

Terry, R. A., and J. M. A. Tilley. 1964. The digestibility of the leaves and stems of perennial ryegrass, cocksfoot, timothy, tall fescue, lucerne and sainfoin, as measured by an in vitro procedure. J. Br. Grassl. Soc. 19:363-372.

Tilley, J. M. A., and R. A. Terry. 1963. A two-stage technique for the in vitro digestion of forage crops. J. Br. Grassl. Soc. 18:104-111.

Weisbjerg, M. R., and T. Hvelplund. 1993 Bestemmelse af nettoenergiindhold (FEK) i råvarer og kraftfoderblandinger [Determination of net energy lactation in straights and compound feedstuffs]. Forskningsrapport nr. 3, Statens Husdyrbrugsforsøg.

Weiss, W. P., and W. L. Shockey. 1991. Value of orchardgrass and alfalfa silages fed with varying amounts of concentrates to dairy cows. J. Dairy Sci. 74:1933-1943.

Yang, W. Z., K. A. Beauchemin, and L. M. Rode. 2001. Effects of grain processing, forage to concentrate ratio, and forage particle size on rumen $\mathrm{pH}$ and digestion by dairy cows. J. Dairy Sci. 84:2203-2216. 